ISSN 0103-5150

Fisioter. Mov., Curitiba, v. 29, n. 2, p. 335-342, Apr./June 2016

Licenciado sob uma Licença Creative Commons DOI: http://dx.doi.org.10.1590/0103-5150.029.002.A012

\title{
Evaluation of functional capabilities in children with Down Syndrome
}

\author{
Avaliação das habilidades funcionais de \\ crianças com Síndrome de Down
}

\author{
Desirée F. Scapinelli ${ }^{[a]}$, Érica Martinho Salvador Laraia ${ }^{[b]}$, Albert Schiaveto de Souza ${ }^{[c]}$ \\ [a] Universidade Anhanguera (UNAES), Campo Grande, MS, Brazil \\ [b] Universidade Anhanguera (UNIDERP), Campo Grande, MS, Brazil \\ [c] Universidade Federal do Mato Grosso do Sul (UFMS), Campo Grande, MS, Brazil
}

\begin{abstract}
Introduction: Down Syndrome (DS) is a chromosomal abnormality characterized by mental retardation of varying degrees and is one of the most commonly found chromosomal aberrations, presenting motor delay such as muscular hypotonic, balance disorders, motor coordination and gait changes. Objective: To evaluate the functional capabilities in children with Down syndrome through the Pediatric Evaluation of Disability Inventory (PEDI). Methods: 20 children of both sexes, 10 with normal motor development (Control group) and 10 with Down syndrome. The functional capabilities were evaluated by PEDI (part I: functional capabilities, part II and III: caregiver assistance and change in environment) through interviews with caregivers. Results: Significant differences were observed in Part I, regarding functional capabilities in self-care $(\mathrm{p}=$ 0.0007), mobility ( $p=0.0007)$ and social function ( $p=0.0002)$, and in Part II, regarding caregiver assistance, the domains of self-care and mobility had $p<0.0001$ and $p=0.001$. In Part III, changes in environment were more frequent when related to Down group. Conclusion: The Down syndrome group has lower
\end{abstract}

*DFS: MSc, e-mail: desireeferroscapinelli@hotmail.com

EMSL: MSc, e-mail: ericasalvador@hotmail.com

ASS: PhD, e-mail: albertss@hotmail.com 
functional performance in both functional capabilities and caregiver assistance, when compared to control group. However, it is clear that this questionnaire provides subsidies to make an early stimulation treatment in order to perform daily skills with the least possible help from their caregivers.

Keywords: Down syndrome. Capability. Evaluation.

\section{Resumo}

Introdução: A Síndrome de Down (SD) é uma anomalia cromossômica caracterizada pelo retardo mental de grau variável e constitui uma das aberrações cromossômicas mais comumente encontradas, apresentando, assim, atraso motor caracterizado por hipotonia muscular, déficit de equilíbrio, coordenação motora e alterações na marcha. Objetivo: Avaliar as habilidades funcionais de crianças com SD através do Pediatric Evaluation of Disability Inventory (PEDI). Materiais e métodos: 20 crianças de ambos os sexos, sendo 10 com desenvolvimento motor normal (grupo controle) e 10 portadoras de Síndrome de Down. As habilidades funcionais foram avaliadas através do PEDI (parte I: habilidades funcionais, parte II e III: assistência do cuidador e modificação do ambiente) por meio de entrevista com os cuidadores. Resultados: Foram observadas diferenças significativas na Parte I, correspondente a habilidades funcionais nas áreas de autocuidado ( $p=0,0007)$, mobilidade $(p=0,0007)$ e função social ( $p=0,0002)$, bem como na parte II, referente a assistência do cuidador, nas áreas de autocuidado e mobilidade com $p<0,0001$ e p=0,001. Já a parte III demonstrou maior frequência de modificações do ambiente relacionadas ao Grupo Down. Conclusão: $O$ grupo de Síndrome de Down possui desempenho funcional menor tanto nas habilidades funcionais quanto na área de assistência ao cuidador quando comparado ao Grupo Controle. Contudo, é visível que através deste questionário são fornecidos subsídios para realizar um tratamento de estimulação precoce, conseguindo assim, realizar suas habilidades diárias com a menor ajuda possível de seus cuidadores.

Palavras-chave: Síndrome de Down. Habilidade. Avaliação.

\section{Introduction}

Studies on children with normal development and with Down Syndrome follow the same trends (1). The cerebrospinal fluid and proximal-distal development is directly related to nerve, muscle and hormonal maturation (2). Motor development refers to movement patterns and capabilities that are acquired throughout life and the age of the individual (3).

Motor development is an orderly, continuous, sequential and progressive process, which takes place from maturation and continues to develop throughout life (4). At each stage, there is a peculiar organization, in which the level of development sequences evolves into more complex levels (5). The motor acquisition in the early years of life is an important factor for predicting the overall development of the child, as the period between birth and the end of the first year of life is characterized by changes that culminate in mobility functions such as crawling and independent walking, respectively at 9 and 12 months of age (6).

Regarding the development of motor skills, evidence reveals that children with Down syndrome delay in the acquisition of basic motor markers, indicating that they emerge later than in children with normal development due to the disorder in chromosome constitution (in this case, the presence of an extra chromosome 21), featuring a simple trisomy $(7,8,9)$. From the cognitive standpoint, it is observed that these children show greater commitment in the area of languages (7). Their motor development occurs more slowly than in other children, taking longer to crawl, sit and walk (10). This may be related to muscle hypotonia due to shortage of downward impulses, which demand a set of motor neurons of the spinal cord. In addition, other studies claim that the excitability of motor neurons are within the normal range during the first months of life and may be due to the delay in cerebellum maturation, cortical pathways $(11,12,13)$ and psychomotor retardation $(14,15)$.

In general, it is observed atypical patterns of postural control, movement and even manipulation of objects. The walk is not rare, however, its movement is broad-based and there is more oscillation of the trunk and head, preventing from keeping the lower members fully extended when standing with certain degree of bending at the level of the hips, knees and 
trunk $(16,17)$. However, besides the neuromotor deficits, developmental delays may also result in limitations of functional capabilities.

The Pediatric Evaluation of Disability Inventory (PEDI) is a North-American standardized testing tool administered through structured interview with the caregiver. It is divided into three parts: Part I - assesses the functional capabilities of the child to perform activities in the domains of self-care (73 items), mobility (59 items) and social function ( 65 items). For each item of Part I, in this test, a score of 1 is assigned (one point) if the child is able to perform the functional activity, or, a score of 0 (zero) if the child is unable. The total score obtained in each scale of this part is the result of the total scores 1 made by the child in the activities included in each function area $(7,18)$.

Part II assesses the child's independence to perform functional tasks in the same three domains, with 8,7 and 5 items, respectively. Each item of this section is scored on an ordinal scale, ranging from score 5 (five), if the child performs the task independently, to score 0 (zero), if the child needs full assistance of their caregiver (19). The third part informs the necessary modifications for the performance of functional tasks in the same three domains described above $(18,19)$. In this part, changes in environment are documented by frequency of responses in nominal scale, which includes four distinct categories: none, child-centered, rehabilitation or extensive. This third part of the test is not characterized as a quantitative scale, since the modifications are not scored (19).

The objective of this study was to evaluate the functional capabilities in children with Down syndrome, and aimed at verifying the independence, mobility, social function and self-care of these children, compared to children with normal motor development for performing functional tasks, and observe the caregiver perception to functional capabilities of children with Down syndrome through PEDI.

\section{Materials and methods}

The sample was composed of 20 children from both sexes, 10 children with normal motor development, corresponding to control group, mean age $54.5 \pm 12.1$ months, and 10 children with Down syndrome corresponding to Down Group, mean age $61.2 \pm 11.8$ months. Inclusion criteria for the study were ages between 3 and 7 years, normal motor development for the Control Group and clinical diagnosis of Down syndrome for Down group. Exclusion criteria were the children with any kind of associated diseases, as well as disorders such as physical disabilities, hearing, visual or speech.

As a tool, it was used the Pediatric Evaluation of Disability Inventory (PEDI) questionnaire, which assesses the functional performance of children with any neurological dysfunction. It documents quantitatively the functional capability of the child, and the independence to carry out activities in their daily life from 6 months to 7 years and 6 months old. It is conducted through structured interview with the parents, or the person who spends most of the day with the child, lasting from 50 to 60 minutes $(6,7)$.

The PEDI is divided into three parts as follows: Part I evaluates the child's functional capabilities to perform activities in the domains of self-care (73 items), mobility (59 items) and social function (65 items). Part II assesses the child's independence to perform functional tasks in the same three domains, with 8, 7 and 5 items, respectively. Part III describes the necessary modifications for the performance of functional tasks in the same three described domains $(18,19)$.

The research project was approved by the Research Ethics Committee in human beings (Universidade Anhanguera - Uniderp) protocol n. 058-2009.

\section{Results}

Twenty children were evaluated, divided into two groups. The control group had mean age of $54.5 \pm 12.1$ months, and Down group $61.2 \pm 11.8$ months ( $\mathrm{p}=0.1933$, Student's t-test for independent samples).

Table 1 represents the distribution of values, regarding age and normative score of PEDI between control group and Down group, showing that the functional capabilities in self-care $(p=0.0007)$, mobility $(\mathrm{p}=0.0007)$ and social function $(\mathrm{p}=0.0002)$ had significant values $p<0.05$. Concerning caregiver's assistance, also related to self-care $(p<0.0001)$, mobility $(p=0.001)$ and social function ( $p=0.1620)$, only the last domain was not significantly different.

Figure 1 represents the comparison between the mean and standard deviation of regulatory score values of Part I - Functional capabilities between the two groups. It was observed that control group's score in the three domains - self-care $(\mathrm{p}=0.0007)$, mobility 
$(\mathrm{p}=0.0007)$ and social function $(\mathrm{p}=0.0002)$ were significant ( $\mathrm{p}<0.05)$, compared to Down group.

In relation to figure 2 , a comparison was made between the mean scores of normative score values in Part II - Caregiver assistance between the two groups. The control group excelled in the domains of selfcare $(\mathrm{p}<0.0001)$ and mobility $(\mathrm{p}=0.001)$ and, only in social function, the Down group obtained a value $(\mathrm{p}=1620)$ with no significant difference $(\mathrm{p}<0.05)$.

The results of responses relating to Part III, which shows the necessary modifications for the performance of functional tasks in the three domains of control group, is described in Table 2. It was found that all children had higher scores in "none", which means no assistance

Table 1 - Distribution of age and normative score values (mean $\pm \mathrm{SD}$ ) from PEDI between both groups, 2009. $(N=20)$

\begin{tabular}{|c|c|c|c|}
\hline & $\begin{array}{l}\text { Control } \\
\text { Group }\end{array}$ & Down Group & “p” \\
\hline \multicolumn{4}{|c|}{ Functional Capabilities } \\
\hline Self-Care & $39.7 \pm 15.1$ & $17.7 \pm 8.0$ & $0.0007^{\star}$ \\
\hline Mobility & $46.1 \pm 13.7$ & $19.4 \pm 15.4$ & $0.0007^{\star}$ \\
\hline Social Function & $54.4 \pm 14.5$ & $27.7 \pm 11.3$ & $0.0002^{\star}$ \\
\hline \multicolumn{4}{|c|}{ Caregiver Assistence } \\
\hline Self-Care & $52.0 \pm 7.1$ & $29.0 \pm 12.2$ & $<0.0001^{*}$ \\
\hline Mobility & $37.0 \pm 19.8$ & $11.1 \pm 3.5$ & $0.001 *$ \\
\hline Social Function & $36.5 \pm 5.9$ & $24.6 \pm 20.0$ & $0.1620 \mathrm{~ns}$ \\
\hline
\end{tabular}

Note: Source: research data

${ }^{*} p<0.05$; ns (not significant) from the caregiver to perform tasks in the three domains (self-care, mobility and social function).

As for the group with Down syndrome, the results also relating to Part III, it was observed that, in selfcare domain, six children scored no modification to be made, one needed help, and three made even in "none" and in "child" by making their own adaptation. Regarding mobility, all children had a high score in "no adaptation" and in social function, but one child had changes by self-performance. The remaining children did not have any adaptation (Table 3 ).

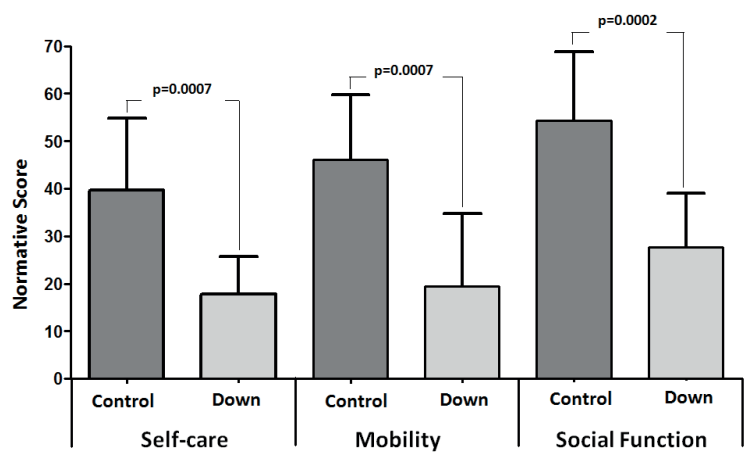

Figure 1 - Comparison between mean and standard deviation of the normative score values of Part I - Functional Capabilities of PEDI between both groups. $(n=20)$

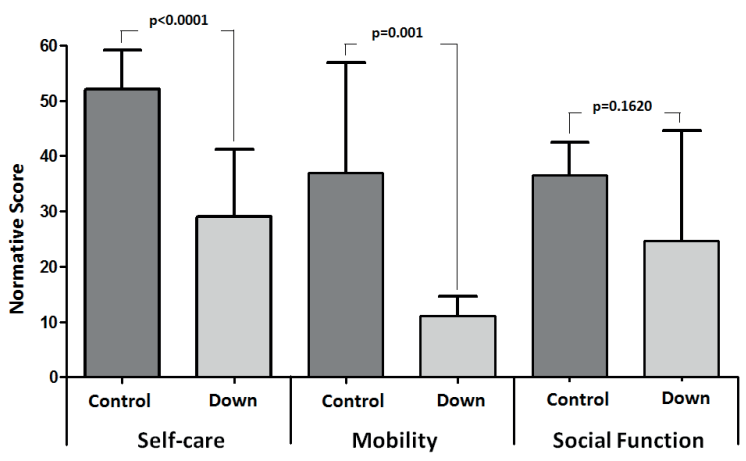

Figure 2 - Comparison of mean scores for normative score in Part II Caregiver Assistance of PEDI between both groups. $(n=20)$ 
Table 2 - Frequency of responses concerning Part III - Change in Environment for control group $(n=10)$

\begin{tabular}{ccccc|cccc|cccc}
\hline \multicolumn{4}{c}{ Self-care (8 items) } & \multicolumn{5}{c|}{ Mobility (7 items) } & \multicolumn{3}{c}{ Social Function (5 items) } \\
$\mathbf{N}$ & Non & Chd & Rea & Ext & Non & Chd & Rea & Ext & Non & Chd & Rea & Ext \\
$\mathbf{1}$ & 6 & 2 & - & - & 3 & 4 & - & - & 2 & 3 & - & - \\
$\mathbf{2}$ & 8 & - & - & - & 2 & 4 & - & - & 3 & 2 & - & - \\
$\mathbf{3}$ & 6 & 2 & - & - & 2 & 5 & - & - & 2 & 3 & - & - \\
$\mathbf{4}$ & 5 & 3 & - & - & 4 & 3 & - & - & - & 5 & - & - \\
$\mathbf{5}$ & 8 & - & - & - & - & 7 & - & - & 2 & 3 & - & - \\
$\mathbf{6}$ & 8 & - & - & - & 1 & 6 & - & - & 1 & 4 & - & - \\
$\mathbf{7}$ & 5 & 3 & - & - & 4 & 3 & - & - & 2 & 3 & - & - \\
$\mathbf{8}$ & 4 & 4 & - & - & 4 & 3 & - & - & 2 & 3 & - & - \\
$\mathbf{9}$ & 6 & 2 & - & - & 3 & 4 & - & - & 3 & 2 & - & - \\
$\mathbf{1 0}$ & 5 & 3 & - & - & 3 & 4 & - & - & 2 & 3 & -
\end{tabular}

Note: $=$ none; Chd $=$ child; Rea $=$ rehabilitation; Ext $=$ extensive

Table 3 - Frequency of responses concerning Part III - Change in Environment for Down group ( $n=10$ )

\begin{tabular}{ccccc|cccc|cccc}
\hline \multicolumn{4}{c}{ Self-care (8 items) } & \multicolumn{5}{c|}{ Mobility (7 items) } & \multicolumn{3}{c}{ Social Function (5 items) } \\
$\mathbf{N}$ & Non & Chd & Rea & Ext & Non & Chd & Rea & Ext & Non & Chd & Rea & Ext \\
$\mathbf{1}$ & 5 & 3 & - & - & 7 & - & - & - & 5 & - & - & - \\
$\mathbf{2}$ & 2 & 6 & - & - & 7 & - & - & - & 5 & - & - & - \\
$\mathbf{3}$ & 6 & 2 & - & - & 7 & - & - & - & 5 & - & - & - \\
$\mathbf{4}$ & 7 & 1 & - & - & 7 & - & - & - & 5 & - & - & - \\
$\mathbf{5}$ & 5 & 3 & - & - & 6 & 1 & - & - & 5 & - & - & - \\
$\mathbf{6}$ & 4 & 4 & - & - & 7 & - & - & - & 5 & - & - & - \\
$\mathbf{7}$ & 7 & 1 & - & - & 7 & - & - & - & 5 & - & - & - \\
$\mathbf{8}$ & 5 & 3 & - & - & 6 & 1 & - & - & 2 & 3 & - & - \\
$\mathbf{9}$ & 4 & 4 & - & - & 3 & 2 & 2 & - & 5 & - & - & - \\
$\mathbf{1 0}$ & 4 & 4 & - & - & 5 & 2 & - & - & 3 & 2 & -
\end{tabular}

Note: $=$ none; Chd $=$ child; Rea $=$ rehabilitation; Ext $=$ extensive

\section{Discussion}

Chromosomes may undergo, occasionally, some modifications during the meiotic and mitotic process, leading to chromosomal changes. Aneuploidy is known as clinically significant chromosomal abnormality (abnormal number of chromosomes due to an extra or missing copy) (21). The presence of an extra chromosome is called trisomy (three instead of the usual pair of a chromosome). It is a result of chromosomal nondisjunction, occurring, mostly, during the meiotic process I (one), thus leading to Down syndrome. This is one of the disorders of genetic etiology recognized for more than a century by John Langdon-Down $(8,21,22,23)$.

Despite showing that the functional performance of children with DS is lower than that of children with normal development, in this study, continuous development is not constant. That confirms the study by Ramalho et al. (24), which shows that children with DS follow the same sequence of movements, going through the same motor milestones, though there may be differences in the pace by which such milestones are reached $(1,24)$. This is due to the changes in the nervous system, which reflect the inability to produce and control appropriate muscle contractions for movement performance, and this influences the walking development, since it depends on the evolution of progressive corticalization of the central nervous (1).

Given the importance of the evaluation of functional capabilities (PEDI), one should take into account that it constitutes an integrated process involving several steps such as mobility, social function and self-care (20). By correlating the study by Pazin et 
al. with the present study, in relation to functional performance, children had lower scores, compared to children with normal development in the three functional domains. These findings confirm evidence in the literature regarding the psychomotor retardation in children with DS (25).

Regarding functional capabilities (part I), there were no statistically significant differences in the domains of mobility, self-care and social function. In the study by Coppede et al. on self-care, children with DS also scored lower than usual, confirming the hypotheses (24). These results are similar to previous studies, which have attributed such delay to the syndrome characteristics and to overprotective parents, who restrict the participation of children in self-care activities $(26,27)$. For the part referring to caregiver assistance (part II), there was no statistically significant difference in the domain of social function, concluding that children with DS need the same caregiver assistance in relation to children with normal development (control group).

However, in the study by Hallal et al., conducted with children with Down syndrome, it was observed by means of normative scores than in the domain of mobility, they had progressed through early stimulation treatment compared to most children with normal motor development $(16,17)$. Moreover, according to Guérios \& Gomes, the matrix analysis of the movement patterns showed that patients with DS, when stimulated early, can have normal motor levels or even higher than the ideal maturity, in accordance with some studies $(16,17,28)$.

In this study, the results were significant in relation to mobility in the domain of functional capabilities showing that these children with Down syndrome acquire them over time. According to Pazin (2007) (26), the development and maturation of children with Down syndrome are near those presented by children with normal development as regards the overall motor skills. These results suggest that, as the child with DS acquires capabilities in the area of mobility, they are incorporated in their daily activities, and thus, getting less help from caregiver $(26,29,30)$.

In studies conducted in children with cerebral palsy, it was found that all patients had results below normal in the area of mobility in functional capabilities (6), which is compared in this study with children with Down syndrome who also had scores below normal. Regarding social function in caregiver assistance, the vast majority of patients with cerebral palsy had values close to normality and, by correlating with children with Down syndrome, they obtained values below normal resulting that they need caregiver assistance (6). By correlating chronological age versus social function within the functional capabilities (part I), there was no significant correlation, a result which confirms the literature (1) by highlighting that the performance of these children is lower in activities involving expressive communication, understanding and socialization, characteristics inherent to the pathology which affects the cognitive development of these children.

\section{Conclusion}

The PEDI questionnaire proved to be effective for the objectives proposed in this study for featuring satisfactorily the functional profile in the areas of mobility, self-care and social function of children with Down syndrome. So, it was considered a very useful tool in the evaluation, besides enabling a critical analysis of this work.

The results presented in this study provide subsidies to state that children with DS have functional performance level lower than control group in both functional capabilities and in the field of caregiver assistance, except in the area of social function. In the latter, it was found that the two groups need the same assistance from the caregiver. It is also noticeable that, through this questionnaire, subsidies are provided to contemplate an early stimulation treatment, causing these children to be stimulated to perform their daily skills with the lowest possible help from their caregivers.

\section{References}

1. Araújo AGS, Scartezini CM, Krebs RJ. Análise da marcha em crianças portadoras de Síndrome de Down e crianças normais com idade de 2 a 5 anos. Fisioter Mov. 2007; 20(3): 79-85.

2. Ferreira MEC. Desenvolvimento perceptivo motor de crianças com Síndrome de Down e paralisia cerebral. Sobama. 1997; 2(2): 17-22.

3. Connolly K. Desenvolvimento motor: passado, presente e futuro. Rev Paul Educ Fís. 2000; Supl 3: 6-15.

4. Perrotti AC, Manoel EJ. Uma visão epigenética do desenvolvimento motor. ver Bras Ciên e Mov. 2001; 9(4): 77-82. 
5. Gimenez R, Manoel EJ, Oliveira DL, Basso L. Combinação de padrões fundamentais de movimento: crianças portadoras de Síndrome de Down. Rev Bras Educ Fís Esp. 2004; 18(1): 101-16.

6. Herrero D, Monteiro CBM. Verificação das habilidades funcionais e necessidades de auxílio do cuidador em crianças com paralisia cerebral nos primeiros meses de vida. ver Bras Crescimento Desenv Hum. 2008; 18 (2): 163-9.

7. Mancini MC, Teixeira S, Araujo LG de, Paixão MC, Magalhaes LC de, Coelho ZAC, et al. Estudo do desenvolvimento da função motora aos 8 e 12 meses de idade em crianças pré-termo e a termo. Arq Neuropsiquiatr. 2002; 60(4): 974-80.

8. Silva NLP, Dessen MA. Síndrome de Down: etiologia, caracterização e impacto na família. Interação em Psicologia. 2002; 6(2): 167 - 6.

9. Bahniuk ME, Koerich MS, Bastos JC. Processos fonológicos em crianças portadoras de Síndrome de Down. Distúrbios Comun.2004; 16(1): 93 - 9.

10. Lara MA, Rodrigues ME. Desenvolvimento motor em crianças portadoras de Síndrome de Down de 4 a 10 anos. Rev Digital Buenos Aires. 2008; 13(124).

11. Garcias GL, Roth MGM, Mesko GE, Boff TA. Aspectos do desenvolvimento neuropsicomotor na Síndrome de Down. REv Bras Neurol. 1995; 31(6): 245 - 48.

12. Freitas FC, Oliveira SJ. Intervenção fisioterápica precoce e seu efeito para aquisição de marcha em crianças com Síndrome de Down. Rev Univ Cat Goiás. 2005; 32(4): 569 - 77.

13. Benda RN, Ugrinowitsch H. Desenvolvimento motor e a perspectiva ecológica de Gibson. Rev Univ Guar Ciên Biol Saú. 1999; 5(5): 135 - 42.

14. Sarro KJ, Salina ME. Estudo de alguns fatores que influenciam no desenvolvimento das aquisições motoras de crianças portadoras de Síndrome de Down em tratamento fisioterápico. Fisioter Mov. 1999; 13(1): 93-106.

15. Fidler DJ, Hepburn SL, Mankin G, Rogers SJ. Praxis capabilities in young children with Down Syndrome, other developmental disabilities, and typically developing children. Am J OccupTher. 2005; 59(2): 129 - 38.

16. Hallal CZ, Marques NR, Braccialli LMP. Aquisição de habilidades funcionais na área de mobilidade em crianças atendidas em um programa de estimulação precoce. Rev Bras Crescimento Desenvolv Hum. 2008; 18(1): 27-34.
17. Mancini MC, Silva PC, Gonçales SC, Martins SM. Comparação do Desempenho funcional de crianças portadoras de Síndrome de Down e crianças com desenvolvimento normal aos 2 e 5 anos de idade. Arq Neuro-Psiquiatr. 2003; 61(2-B): 409-15.

18. Marinho APS, Souza MAB, Pimentel AD. Desempenho Funcional de crianças com paralisia cerebral diparéticas e hemiparéticas. R Ci Méd Biol. 2008; 7(1): 57-66.

19. Lyer LV, Haley SM, Watkins MP, Dumas HM. Establishing minimal clinically important differences for scores on the pediatric evaluation of disability inventory for inpatient rehabilitation. Phys Ther. 2003. 83(10): 888-98.

20. Herrero, D, Monteiro, CBM. Verificação das habilidades funcionais e necessidades de auxílio do cuidador em crianças com paralisia cerebral nos primeiros meses de vida. Rev Bras Crescimento Desenvolv Hum. São Paulo; 18(2): 163 - 9.

21. Nakadonari EK, Soares AS. Síndrome de Down: considerações gerais sobre a influência da idade materna avançada. Arq Mudi. 2006; 10(2): 5-9.

22. Moreira LMA, El-Hani CN, Gusmão FAF. A síndrome de Down e sua patogênese: considerações sobre o determinismo genético. Rev Bras Psiquiatr. 2000; 22(2): 96-9.

23. Lorena SHT. Síndrome de Down: epidemiologia alterações oftalmológicas. Rev Bras Oftalmol. São Paulo. 2012; 71(3): 188 - 90.

24. Ramalho CMJ, Pedremônico MR, Perissinoto J. Síndrome de Down: avaliação do desempenho motor, coordenação e linguagem (entre dois e cinco anos). Team Desenvol. 2000; 9(52): 11-4.

25. Kasari C, Freeman SFN. Task-related social behavior in children with Down syndrome. Am J Ment Retard. 2001; 106(3): 253-64.

26. Pazin AC, Martins MRI. Desempenho funcional de crianças com Síndrome de Down e a qualidade de vida de seus cuidadores. Rev Neurocienc. 2007;15(4): 297-303.

27. Silva NL, Dessen MA. Crianças com síndrome de Down e suas interações familiares. Psicol Reflex Crit. 2003;16(3): 503-14.

28. Guérios LC, Gomes NM. Análise de um programa para desenvolvimento dos padrões fundamentais de movimento em crianças portadoras de Síndrome de Down. Rev Dig. 2005; 10(83): 225 - 9. 
29. Coppede AC, Campos AC, Santos DCC, Rocha NACF. Desempenho motor fino e funcionalidade em crianças com síndrome de Down. Fisioter Pesq. 2012; 19(4):363-8.

30. Moreira LMA, El-Hani CN, Gusmão FAF. A síndrome de Down e sua patogênese: considerações sobre o determinismogenético. Rev Bras Psiquiatr. 2000; 22(2):96-9.

Received: 07/05/2013

Recebido: 05/07/2013

Aproved: 09/17/2015

Aprovado: 17/09/2015 